\title{
TESTING WAGNER'S LAW FOR TURKEY: EVIDENCE FROM A TRIVARIATE CAUSALITY ANALYSIS
}

\author{
Asuman Oktayer, Nagihan Oktayer ${ }^{\star}$
}

\begin{abstract}
:
The purpose of this study is to analyse the relationship between government expenditure and economic growth in Turkey. The study tests the validity of Wagner's law by applying autoregressive distributed lag (ARDL) cointegration technique using annual data over 1950-2010 period. In order to find out the possible impact of omitted variables, we first tested the standard bivariate versions of Wagner's law. In the next step by including a third variable - inflation ratio - the analysis extended on a trivariate system. The findings of each testing procedure indicate that omitted variables matter. Since, while there exists no long-run relationship between the variables in the first step of the testing procedure, a long-run correlation is found in the second step. The differences of this paper from the earlier studies testing the Law for Turkey are that, the causal link is examined within a trivariate framework and non-interest government expenditure is considered instead of total government expenditures.
\end{abstract}

Keywords: Wagner's law, economic growth, government expenditure, trivariate causality test. JEL Classification: E60, H50, O10.

\section{Introduction}

The relationship between government expenditure and economic growth has been an important subject of analysis and debate among economists for decades. There are mainly two different approaches in the literature concerning the relationship between these economic magnitudes. These two well-known approaches are "Wagner's law" and "Keynesian hypothesis".

According to Wagner there is a positive relationship between economic activities and government expenditure (Henrekson, 1993). By an increase in economic activity, an upward trend in government activity occurs. In contrast with Wagner's proposition, Keynesian view assumes that growing government expenditure may lead to a higher level of aggregate demand, which in turn promotes economic growth.

As Singh and Sahni (1984) stated, the relationship between government expenditure and national income has been treated in different ways in two areas of economic analysis. While at Wagner's side, an increase in government expenditure is accepted to

* Asuman Oktayer, Yildiz Technical University, Faculty of Economics and Administrative Sciences (aoktayer@yildiz.edu.tr); Nagihan Oktayer, Istanbul University, Faculty of Economics (noktayer@ istanbul.edu.tr). 
be induced by growth in national income, at Keynesian side, it is accepted that income growth is ascertained by an increase in government expenditure. Wagner's law has attracted a great deal of attention in the public finance literature since 1960s.

Therefore, Wagnerian and Keynesian approaches represent two alternative viewpoints in explaining the causality between government expenditure and national income. While Wagnerian approach states that, the causality runs from economic development to government expenditure, according to the Keynesian approach, the direction of causality runs in the opposite side.

The government expenditure-national income nexus is important for some policyrelated issues, especially in fighting with cyclical fluctuations. Fiscal policy is one of the most important policy tools in recessionary periods for governments. For example, central authorities can stimulate their economy by increasing the share of government spending to national income. The estimation of long-run relationship between government expenditure and national income in advance would permit the identification of a benchmark against which one can identify the fiscal policy stance adopted by particular governments (Kumar, Webber and Fargher, 2009).

\section{Theoretical Background}

The role and the size of public sector in many developed countries increased especially after the World War II considerably. This increase led to the development of a large number of explanations for changes in the size of public sector. Beside economic explanations, there are some studies considering fiscal, political, institutional and international dimensions of expansion as well, which are out of scope for this study. In the context of economic explanations, Wagner's model, which is originally called as "the Law of Increasing State Activity" is one of the earliest attempts in this field and attracted great attention worldwide.

In 1893, the German political economist Adolph Wagner put forward his well-known proposition that regards public expenditure growth as a natural consequence of economic growth. He did not express his ideas in the form of a law and avoided making definitive formulations. His views were later formulated as a law and came to be known as "Wagner's law" or "Wagner's hypothesis" (Henrekson, 1993; Halicioglu, 2003).

The Law suggests that an expansion of a country's level of economic development leads to an increase in its relative size of public sector. This statement includes a comparison of development between private and public sectors. According to Wagner's law as the national economy grows, the public sector will grow at a faster rate than the private sector. There are several underlying reasons causing this result. First, with economic growth, industrialization and urbanization would generate an increase in government expenditures. Development of the economies makes legal relationships between the economic agents more complex, which triggers the administrative, regulatory and protective functions of the government. Second, real income growth would lead 
to a higher level of demand for basic infrastructure. In such a case, there would be a need for increased provision of social and cultural goods and services. As a result, as economy develops, expenditures on social welfare of society such as education and health expand. Third, government has to interfere to the market to ensure the functioning of natural monopolies and to enhance economic efficiency (Bird, 1971).

Following the explanations and debates on theoretical level, Wagner's law has been empirically tested by various researchers. The empirical evidence concerning the relationship between public income and expenditure is based on the assessment of the elasticity of expenditure to income. Only if such elasticity is superior to the unit and the coefficient sign is positive, it can be affirmed that the link between the two variables exists and it is consistent with Wagner's hypothesis.

As pointed out by Dutt and Ghosh (1997), Wagner did not present his Law in a mathematical form and he was not explicit in the formulation of his hypothesis. Therefore, over the years, different mathematical forms have been applied by the authors. There are at least six different versions of the Law. Several empirical specifications have been introduced to test the Wagner's law in different versions. The most well-known of these versions can be summarized as follows:

\section{Version 1 -}

$$
\ln G_{t}=\alpha_{0}+\alpha_{1} \ln Y_{t}+e_{t}
$$$$
\alpha_{1}>1
$$

where $\mathbf{G}_{\mathbf{t}}$ is the real total government expenditures, $\mathbf{G C}_{\mathbf{t}}$ is real government consumption expenditures, $Y_{t}$ is real income, and $\mathrm{P}$ is population.

Functional form 1 is referred to as the Peacock-Wiseman (1979) version. In this version, support for Wagner's hypothesis requires that the $\alpha_{1}$ parameter, which represents the elasticity of government expenditures with respect to output, exceeds unity.

\section{Version 2 -}

$$
\ln (\mathbf{G} / \mathbf{Y})_{t}=\beta_{0}+\beta_{1} \ln Y_{t}+e_{t}
$$$$
\beta_{1}>1
$$

Functional form 2, proposed by Mann (1980), represents the modified version of Peacock-Wiseman. In this model, the share of government expenditures in total output is a function of real output. Here, the validity of Wagner's hypothesis requires that the elasticity of government share in total output with respect to output exceed zero.

\section{Version 3 -}

$$
\ln (\mathbf{G} / \mathbf{Y})_{t}=\gamma_{0}+\gamma_{1} \ln (\llbracket Y / P) \rrbracket_{t}+e_{t}
$$

Functional form 3 was proposed by Musgrave (1969). In this version, the share of real government expenditures to output is a function of real per capita output. The validity of Wagner's hypothesis requires the parameter $\gamma_{1}$ representing the elasticity of government expenditures with respect to real output per capita, exceed zero.

Version 4 -

$$
\ln (\mathbf{G} / \mathbf{P})_{t}=\delta_{0}+\delta_{1} \ln (\llbracket Y / P) \rrbracket_{t}+e_{t}
$$$$
\delta_{1}>1
$$ 
Functional form 4 is called as the Gupta version (1967). This specification models real per capita government expenditures as a function of real per capita output. Support for the hypothesis requires that the elasticity of per capita real government expenditures with respect to real per capita output exceed unity.

\section{Version 5 -}

$$
\ln \mathbf{G t}=\rho_{0}+\rho_{1} \ln (\llbracket Y / P) \rrbracket_{t}+e_{t}
$$$$
\rho_{1}>1
$$

In the functional form 5, which is called as the Goffman (1968) version, the real government expenditures are modelled as a function of real per capita output. Here, support for the hypothesis requires that the elasticity of real government expenditures with respect to per capita output exceed unity.

\section{Version 6 -}

$$
\ln G C_{t}=\theta_{0}+\theta_{1} \ln Y_{t}+e_{t}
$$$$
\theta_{1}>1
$$

Finally, in the last version, which is adopted by Pryor (1968), real government consumption expenditures are accepted as a function of real output. Support for the hypothesis requires that the elasticity of government consumption with respect to income exceed unity.

\section{Literature Review}

Because of government expenditure's importance as a policy tool in economics, the relationship between government expenditure and economic growth has been one of the most widely investigated issue especially since the post-Second World War. The validity of the Law has been assessed empirically for a large number of developing and developed countries using both time series and cross sectional data sets. The studies cover country-specific analyses as well as analyses of groups of economies.

Most of the empirical studies are based on cross-sectional data within cross-country growth regressions, and, hence, provides only pooled estimates of the relationship between government expenditure and national income. The major shortcoming of these studies is that these kinds of regressions do not capture the dynamics of the relationship between these two variables and ignore country-specific factors (Ghali, 1998). Thus, empirical studies aiming to test the validity of Wagner's law should base on time-series analysis of public expenditure in any country for as long a time period as possible.

Comparing to cross sectional data sets, very few studies use time series analysis in the literature. On the other hand, although time-series analysis is the most appropriate methodology, it has to be emphasized that especially earlier time-series studies are far from perfections. These studies supposed that the time-series data were stationary, so inappropriate evaluation techniques had consequently been used. The empirical results of these studies, with a few exceptions provide strong support for the law. Studies conducted by Peacock and Wiseman (1961), Musgrave (1969), Michas (1975), Mann (1980), Ram $(1986,1987)$ are some of them.

Because of serious shortcomings of earlier test techniques, modern time-series techniques have been developed and recent studies have relied on these new versions. 
While the majority of studies using classical time-series methodology received strong support for the law, the results have started to become more mixed in the new studies. For example, of country specific studies, Gyles (1991) for the UK, Courakis et al. (1993) for Greece and Portugal, Murthy (1993) for Mexico, Oxley (1994) for the UK, Ahsan et al. (1996) for Canada, Lin (1998) for the USA, Abizadeh, Yousefi (1998) for South Korea, Legrenzi Milas (2002) for Italy and Dritsakis, Adamopoulos (2004) for Greece have provided support for the Law in their analyses. On the contrary, Henrekson (1993) for Sweden, Ashworth (1994) for Mexico, Hayo (1994) for Mexico, Hondroyiannis, Papapetrou (1995) for Greece, Chletos, Kollias (1997) for Greece, Ghate, Zak (2002) for the USA, Payne et al. (2006) for the USA and Sinha (2007) for Thailand have found little or no support for the Law.

Wagner's law has been tested empirically for various countries over the years. As it can be observed, findings vary considerably from country to country with some supportive and some opposing evidence. The reasons of conflicting results have been quested by scholars and many explanations have been given. Although these contradictory results are generally attributed to different econometric methodologies used, Ram (1986, 1987) suggests that differences in the nature of underlying data, the test procedure and the period studied may explain the diversity in results. In addition, Ahsan, Kwan and Sahni (1992) add some other factors that may be helpful in explaining the inconsistency amongst the results received by different scholars. Most important of these factors is the influence of "omitted" variables. It is claimed that failure to account for omitted variables can give rise to a misleading causal ordering among the variables. Following to Ghali's (1998) study, Loizides and Vamvoukas (2005) states that a study aiming to examine the causal link between government expenditure and national income has to be based on both bivariate and trivariate frameworks. According to them, one of the most significant weaknesses of many of the earlier studies on that topic was the failure to adjust for the co-integration result of the time series in the case of the trivariate framework. Introduction of a third variable to the system can alter not only the causal inference based on the simple bivariate system, but also the magnitude of the estimates.

Determination of the third variable is significant in that, it should be selected from the variables at the centre of interest of economic policies. As stated by Loizides and Vamvoukas (2005) additional variable(s) should be closely connected with both government expenditures and national income. In this respect, one of the most appropriate variables is inflation rate for two reasons. First, compared with relatively successful period of 1950-1975, Turkey has started to live in a very high and variable inflationary environment after 1975 for approximately three decades. Therefore, inflation is expected to play an important role in the formation of the causal process between government expenditures and national income in the country. Secondly, inflation is found to be related closely with government expenditures and economic growth in some empirical studies.

If we look at the Turkish literature, studies analysing the validity of the Law for Turkey are similar to other country studies in terms of conflicting results. Demirbas (1999), 
Halicioglu (2003), Bagdigen, Cetintas (2004), Cavusoglu (2005), Oktayer, Susam (2008), Bagdigen, Beser (2009), and Basar et al. (2009) have not found any evidence for the Law. Studies conducted by Krzyzaniak (1974), Ram (1987), Yamak, Kucukkale (1997), Terzi (1998), Gunaydin (2000), Sari (2003), Arisoy (2005), Isik, Alagoz (2005), Mohammadi et al. (2008), Yay, Tastan (2009) and Oktayer (2011) have found support in favor of the Law. Most of the studies, except Halicioglu's (2003) study, examining the long-run relationship between government expenditure and national income in Turkey are based on simple bivariate system.

\section{An Overview of the Turkish Economy}

The years between 1950 and 1980 was a period in which protectionist policies dominated in the Turkish economy. Before 1980, Turkey had a relatively closed and regulated economy. Development strategy of the country was import substitution. The economy had almost not faced with any external shocks until the 1970s. Turkey entered the inflationary period by the effect of international Oil Crises in the beginning of the second half of the 1970s and abandoned the import substitution development strategy with a big crisis with huge amounts of foreign debt, balance of payment deficits, high inflation and negative growth rate at the end of the decade (Yay and Tastan, 2009).

At the beginning of the 1980s, the Turkish economy had begun to undergo an in-depth transformation period. Substantial changes and measures had taken place in the economy. One of the most important of them was the introduction of a stabilization program. January 1980 was the reversal of the earlier policies. Beside economic stabilization program, export-led growth strategy was adopted in the economy (Ertugrul and Selcuk, 2001). The Turkish economy was liberalized step by step by means of market-based structural reforms during the 1980s. It has moved from a protected state-directed system to a market oriented free enterprise system. Reforms initiated in 1980 have largely reduced the role of the government in the economy.

Fighting with high inflation rates, reduction of current account and public sector deficits and creation of more sustainable fiscal conditions were the key concerns of the post-1980 adjustment efforts (Celasun, 1990). The new strategy of the early 1980s was quite successful. The average annual growth rate of the real GNP was an impressive 5.8 percent between 1981 and 1988. Economy did not experience any recession by the end of 1987. The inflation was brought down from three digit levels in 1980 to about $30 \%$ in 1982 with a small output loss. During the first two years of the program, the current account deficit was halved from a level of $5 \%$ of GNP, and the public sector borrowing requirement fell from $10 \%$ of GNP to less than $4 \%$ (Akyuz, Boratav, 2002). In sum, until 1988, the program had been applied successfully and almost all indicators of the economy improved.

Starting from the late 1980s macroeconomic instability increased and it remained as an endemic characteristic of the Turkish economy during the 1990s. Political instability 
and related populist and myopic policies, and associated problems of public sector imbalances were blamed for the persistence of high macroeconomic instability (Ozatay, 1999). The liberalization of international capital flows made Turkish financial markets more fragile. In this period, public expenditures and budget deficit displayed rapid increases and their shares in GNP reached $35 \%$ and $12 \%$, respectively. The increases were financed by government debts. Turkish banking system, with its weak and unready structure to international competition, was not able to sustain its functions between government excess debt policy and high international capital flows in the absence of effective regulation. Turkey experienced three most important crises of its history in six years (1994, 2000 and 2001). The shares of public expenditures and budget deficit in GDP were raised to $46 \%$ and $17 \%$ respectively in 1999-2001 (Yay, Yay, Tastan, 2002; Yay, Tastan, 2009).

The Turkish economy has gone through considerable changes in the aftermath of the 2001 crisis. After a decade of failed reforms and deteriorated macroeconomic performance, Turkey entered a new phase under a new economic program. The macroeconomic scene has changed dramatically with monetary authorities adopting an inflation targeting policy to reduce the double-digit inflation rate (around 70 percent by the end of 2001) to single digits. Additionally, the government has applied a prudent fiscal policy to reduce its overall debt, with a commitment to run a primary surplus of 6.5 percent of GDP. Macroeconomic instability fell dramatically from 2002 and Turkey experienced an unprecedented economic growth rate. Real GDP grew very rapidly at an annual average of $7.1 \%$, during the 2002-2006 period. Fiscal discipline led to a significant improvement in the budgetary primary balance in this period. Reduced interest payments mirroring a decline in the risk premium also helped the decline in the central government's budget balance. The shares of public expenditures and budget deficit in GDP declined to $28.1 \%$ and 5.4\% respectively in 2002-2006 period. Decisive change in macroeconomic policy, especially important structural reforms implemented after the 2001 crisis has played a crucial role in this improvement.

Starting from 2007, deterioration has started in the macroeconomic indicators. The general elections performed in 2007 and then the global financial crisis in 2008 contributed to this deterioration. Turkish economy recorded a sharp decline in growth (from $6.9 \%$ in 2006 to $-4.7 \%$ in 2009 ) and serious increase in budget deficit (from $0.6 \%$ in 2006 to $-5.5 \%$ in 2009). However, comparing to other countries, Turkish economy has shown a strong resistance to destructive effects of the global crisis with the impact of the structural reforms implemented after 2001.

Consequently, one of the most problematic issues of the Turkish economy has been inflation over the years. The Turkish economy has experienced relatively high inflation and unsuccessful disinflation programs until the 2000s. High and variable inflation has been a central feature of the Turkish economy since 1970s in that sense. Turkish inflation grew from single-digit levels in the 1960s and reached its first peak in 1980 at more than 80 percent. After reaching a second peak of 125 percent in 1994, inflation started 
a downward trend in response to a series of stabilization measures that were introduced in the same year. Throughout the second half of the 1990s, inflation continued to fluctuate within a 70-100 percent range. However, after the introduction of the 1999 Disinflation and Fiscal Adjustment Program and the three-year standby agreement signed with the International Monetary Fund, inflation dropped significantly from multi-digit levels to single-digit ones.

\section{Econometric Methodology}

To test the existence of a long-run relationship between the variables related to Wagner's law in Turkey, the first five versions of Wagner's law stated in the previous section have been estimated by using autoregressive distributed lag - ARDL - cointegration procedure (or the bounds testing procedure) developed by Peseran et al. (2001) in a trivariate system. Before applying bounds testing procedure, stationarity of variables should be investigated.

Unit Root Tests: Because the presence of unit root makes the regression results spurious and thus disturbs the accuracy of the parameters estimated, in the first stage, stationarity of the time series data is tested by implementing unit root tests. Although the ARDL testing approach does not necessitate unit root tests, it is important to perform the unit root test in order to ensure that no variable is integrated of order two or higher. This is because the ARDL procedure assumes that all variables are either $\mathrm{I}(0)$ or $\mathrm{I}(1)$. If one of the variables in the model is found to be I(2), then the computed F-statistics produced by Pesaran et al, (2001) and Narayan (2005), can no longer be valid.

Among a number of alternative tests, we test for the unit roots of the variables using three different tests, namely the Augmented Dickey-Fuller test (hereafter ADF), developed by Dickey and Fuller (1979), the test developed by Elliott, Rothenberg and Stock (1996, hereafter DF-GLS) and the Zivot-Andrews test (hereafter ZA) developed by Zivot and Andrews (1992).

The problem with the conventional unit root tests such as ADF and DF-GLS is that they do not allow for the possibility of structural break. Assuming the time of the break as an exogenous phenomenon, Perron (1989) showed that the power to reject a unit root hypothesis decreases when the stationary alternative is true and the structural break is ignored. Therefore, failure to find significant evidence of stationarity from the conventional unit root tests may reflect misspecification of the deterministic trend. Zivot and Adrews (1992) proposed a variation of Perron's (1989) original test in which they assume that the exact time of the break point is unknown. To investigate whether or not there is a structural break, the Zivot-Andrews unit root test is thirdly performed in this study.

ARDL Specification: The approach has certain econometric advantages in comparison to other cointegration tests (Engle and Granger, 1987; Johansen, 1988; Johansen and Juselius, 1990). First of all it is not important whether the series are I(0) or I(1). The test is applicable irrespective of whether the regressors in the model are purely $\mathrm{I}(0)$, 
purely I(1) or mutually cointegrated; however, it crashes if the series are I(2). Another advantage of the ARDL approach is that it relatively provides more robust results and super consistent estimates of the long-run coefficients in case of small samples.

In a bivariate model the Bounds testing procedure analyses a possible long-run relationship in the form of the unrestricted vector error correction model given below:

$$
\Delta Y_{t}=c_{0}+\sum_{j=1}^{n} \varphi_{j} \Delta Y_{t-j}+\sum_{j=1}^{m} \varpi j \Delta X_{t-j}+\mu_{1} Y_{t-1}+\mu_{2} X_{t-1}+\varepsilon_{t}
$$

where $\mathrm{Y}$ is the dependent and $\mathrm{X}$ is the independent variable, $\Delta$ is the first difference operator and $\varepsilon_{t}$ is the error term.

To investigate the existence of a long-run relationship among the variables in the bounds cointegration procedure, the first step is to apply ordinary least squares (OLS) regression to equation (1) by performing a Wald test (F statistics) for the joint significance of the coefficients of the lagged levels of the variables; $H_{0}: \mu_{1}=\mu_{2}=0$ implying no cointegration and implying at least one cointegrating equation and thus a long-run relationship. Peseran et al. (2001) present two sets of asymptotic critical values for testing cointegration for a given significance level. The set with lower value is computed assuming that the regressors are $\mathrm{I}(0)$ and the other set with upper value is computed assuming that the regressors are $\mathrm{I}(1)$. If the computed $\mathrm{F}$ statistics exceeds the upper critical value, the null hypothesis of no cointegration can be rejected. If it falls below the lower critical value the null hypothesis cannot be rejected. Finally, if the F statistics value falls between the lower and upper critical values the result is inconclusive.

If there exists a long-run relationship among the variables, the second step is to estimate the long-run model for $Y_{t}$ by selecting the orders of ARDL $(n, m)$ model in variables using the AIC (Akaike information criteria):

$$
Y_{t}=C_{0}+\sum_{j=1}^{n} \mu_{1} Y_{t-j}+\sum_{j=0}^{m} \mu_{2} X_{t-j}+\varepsilon_{t}
$$

In the final step of the bounds testing procedure short-run dynamic parameters are obtained by estimating an error correction model (ECM) associated with the long-run estimates. In order to estimate the speed of adjustment of the dependent variable to independent variable(s), the lagged level variables in equation (1) are replaced by ect $t_{t-1}$ :

$$
\Delta Y t=\gamma+\sum_{j=1}^{n} \varphi_{j} \Delta Y_{t-j}+\sum_{j=0}^{m} \varpi_{j} \Delta X_{t-j}+\lambda e c t_{t-1}+\varepsilon_{t}
$$

In equation (3), $\varphi_{j}$ and $\varpi_{j}$ are the short-run dynamic coefficients of the model's convergence to equilibrium, $\lambda$ is the speed of adjustment and ect is the error correction term derived from the long-run relationship. If the value of speed of adjustment is zero it means that there exist no long-run relationships, if it's between -1 and 0 , there exists partial adjustment. A value smaller than "-1" indicates that the model overadjusts in the current period; finally a positive value implies that the system moves away from equilibrium in the long-run. 


\section{Data}

In this study, we test the validity of Wagner's law in Turkey by performing a cointegration technique using annual data over the period 1950-2010. The definitions of the variables we use in the models are as follows; Y is real GNP, YP is per capita real GNP, G is real non-interest government expenditures, GP is per capita real non-interest government expenditures, GY is the share of non-interest government expenditures in GNP and finally I is inflation rate. All nominal variables were deflated by the 1987 base year GNP deflator to have them in real terms. All variables are expressed in natural logarithms. We obtained data for nominal non-interest government expenditures from the Turkish Ministry of Finance, nominal GNP from the State Planning Organization of Turkey and population and 1987 base year inflation rate from the Turkish Statistical Institute.

\section{Empirical Findings}

Before we implement the ARDL bounds test, we test for the stationarity status of all variables to determine their order of integration by applying three alternative unit root tests. This is to ensure that the variables are not $\mathrm{I}(2)$ stationary and so as to avoid spurious results.

Table 1

Unit Root Test Results (level and first difference)

\begin{tabular}{|c|c|c|c|c|c|c|c|c|}
\hline \multirow{3}{*}{ Variables } & \multicolumn{4}{|c|}{ Augmented Dickey and Fuller Test } & \multicolumn{4}{|c|}{$\begin{array}{l}\text { Elliot, Rothenberg and Stock's } \\
\text { GLS Detrended Test }\end{array}$} \\
\hline & \multicolumn{2}{|c|}{ Level } & \multicolumn{2}{|c|}{ First Difference } & \multicolumn{2}{|c|}{ Level } & \multicolumn{2}{|c|}{ First Difference } \\
\hline & Intercept & $\begin{array}{l}\text { Intercept } \\
\text { \& Trend }\end{array}$ & Intercept & $\begin{array}{l}\text { Intercept } \\
\text { \& Trend }\end{array}$ & Intercept & $\begin{array}{l}\text { Intercept } \\
\text { \& Trend }\end{array}$ & Intercept & $\begin{array}{l}\text { Intercept \& } \\
\text { Trend }\end{array}$ \\
\hline $\ln Y$ & $\begin{array}{c}-1.32 \\
(1)\end{array}$ & $\begin{array}{l}-2.76 \\
(1)\end{array}$ & $\begin{array}{c}-12.99^{* *} \\
(0)\end{array}$ & $\begin{array}{l}-12.13^{* *} \\
(0)\end{array}$ & $\begin{array}{l}2.18 \\
\text { (1) }\end{array}$ & $\begin{array}{c}-1.43 \\
(1)\end{array}$ & $\begin{array}{c}-1.97^{*} \\
(5)\end{array}$ & $\begin{array}{c}-11.36^{* *} \\
(0)\end{array}$ \\
\hline $\ln G$ & $\begin{array}{c}-0.14 \\
(1)\end{array}$ & $\begin{array}{c}-2.45 \\
(0)\end{array}$ & $\begin{array}{c}-9.87^{\star *} \\
(1)\end{array}$ & $\begin{array}{c}-9.97^{\star *} \\
(0)\end{array}$ & $\begin{array}{c}1.64 \\
(0)\end{array}$ & $\begin{array}{c}-2.96 \\
(0)\end{array}$ & $\begin{array}{c}-8.90^{* *} \\
(0)\end{array}$ & $\begin{array}{c}-9.18^{\star *} \\
(0)\end{array}$ \\
\hline InGP & $\begin{array}{c}-1.56 \\
(1)\end{array}$ & $\begin{array}{c}-2.85 \\
(0)\end{array}$ & $\begin{array}{c}-10.21^{* *} \\
(0)\end{array}$ & $\begin{array}{c}-10.37^{* *} \\
(0)\end{array}$ & $\begin{array}{c}1.76 \\
(0)\end{array}$ & $\begin{array}{c}-2.53 \\
(0)\end{array}$ & $\begin{array}{c}-9.77^{\star *} \\
(0)\end{array}$ & $\begin{array}{l}-10.25^{* *} \\
(0)\end{array}$ \\
\hline $\ln G Y$ & $\begin{array}{c}-0.68 \\
(1)\end{array}$ & $\begin{array}{c}-3.00 \\
(0)\end{array}$ & $\begin{array}{c}-9.56^{* *} \\
(0)\end{array}$ & $\begin{array}{c}-9.65^{* *} \\
(0)\end{array}$ & $\begin{array}{c}-0.34 \\
(0)\end{array}$ & $\begin{array}{c}-2.69 \\
(0)\end{array}$ & $\begin{array}{c}-7.47^{* *} \\
(0)\end{array}$ & $\begin{array}{l}-8.68^{* *} \\
(0)\end{array}$ \\
\hline $\operatorname{lnYP}$ & $\begin{array}{c}-0.45 \\
(1)\end{array}$ & $\begin{array}{c}-2.99 \\
(6)\end{array}$ & $\begin{array}{c}-11.92^{* *} \\
(0)\end{array}$ & $\begin{array}{c}-11.44^{* *} \\
(0)\end{array}$ & $\begin{array}{l}1.87 \\
\text { (1) }\end{array}$ & $\begin{array}{c}-2.36 \\
(1)\end{array}$ & $\begin{array}{l}-10.69^{* *} \\
\text { (1) }\end{array}$ & $\begin{array}{c}-11.17^{\star *} \\
(0)\end{array}$ \\
\hline Inl & $\begin{array}{c}-1.49 \\
(0)\end{array}$ & $\begin{array}{c}-1.61 \\
(0)\end{array}$ & $\begin{array}{c}-8.94^{* *} \\
(0)\end{array}$ & $\begin{array}{l}-8.897^{* *} \\
(0)\end{array}$ & $\begin{array}{c}0.940 \\
(0)\end{array}$ & $\begin{array}{c}3.52 \\
(0)\end{array}$ & $\begin{array}{c}-2.986^{* *} \\
(0)\end{array}$ & $\begin{array}{l}-3.199^{*} \\
(0)\end{array}$ \\
\hline $\begin{array}{l}\text { Critical } \\
\text { Values }\end{array}$ & & & & & & & & \\
\hline$\% 1$ & -3.546 & -4.121 & -3.546 & -4.121 & -2.60 & -3.73 & -2.60 & -3.73 \\
\hline$\% 5$ & -2.911 & -3.457 & -2.911 & -3.487 & -1.94 & -3.16 & -1.94 & -3.16 \\
\hline
\end{tabular}

Note: Values in brackets are the lag lengths, which are chosen by using Schwarz information criterion. * ${ }^{* *}$ denotes statistical significance at the $5 \%$ and $1 \%$ levels respectively. The null hypothesis under both the ADF and DF-GLS is that the variable contains a unit root. 
In Table 1 the results of the ADF and DF-GLS test statistics are reported. The results of these unit root tests suggest that all variables in natural logarithm forms are each integrated of order one, I(1). The results of the Zivot-Andrews unit root test, which is able to capture the impact of structural breaks, are given in Table 2. The Zivot-Andrews test with one structural break finds no additional evidence against the unit root null hypothesis relative to the unit root tests without a structural break. In other words, in models $\mathrm{A}, \mathrm{B}$ and $\mathrm{C}$ the null hypotheses are not rejected for the variables. This result is consistent with the standard ADF and DF-GLS test results.

Table 2

Zivot and Andrews Test with One Structural Break

\begin{tabular}{|c|c|c|c|c|c|c|}
\hline \multirow[b]{2}{*}{ Variables } & \multicolumn{2}{|c|}{ Model A } & \multicolumn{2}{|c|}{ Model B } & \multicolumn{2}{|c|}{ Model C } \\
\hline & Break Date & $\begin{array}{c}\text { Test } \\
\text { Statistics }\end{array}$ & Break Date & $\begin{array}{c}\text { Test } \\
\text { Statistics }\end{array}$ & Break Date & $\begin{array}{c}\text { Test } \\
\text { Statistics }\end{array}$ \\
\hline $\ln Y$ & 1966 & $\begin{array}{l}-4.13 \\
(1)\end{array}$ & 1975 & $\begin{array}{c}-3.37 \\
(1)\end{array}$ & 1979 & $\begin{array}{l}-4.00 \\
(1)\end{array}$ \\
\hline $\operatorname{lnYP}$ & 1979 & $\begin{array}{c}-4.44 \\
(0)\end{array}$ & 1988 & $\begin{array}{c}-5.29 \\
(0)\end{array}$ & 2000 & $\begin{array}{l}-4.99 \\
(0)\end{array}$ \\
\hline $\ln G$ & 1980 & $\begin{array}{l}-4.20 \\
(0)\end{array}$ & 1986 & $\begin{array}{c}-2.76 \\
(0)\end{array}$ & 1980 & $\begin{array}{c}-4.42 \\
(0)\end{array}$ \\
\hline $\ln G P$ & 1996 & $\begin{array}{c}-3.88 \\
(0)\end{array}$ & 1986 & $\begin{array}{c}-3.10 \\
(0)\end{array}$ & 1981 & $\begin{array}{c}-4.20 \\
(0)\end{array}$ \\
\hline $\ln G Y$ & 1996 & $\begin{array}{l}-4.00 \\
(0)\end{array}$ & 1986 & $\begin{array}{c}-3.27 \\
(0)\end{array}$ & 1999 & $\begin{array}{l}-4.18 \\
(0)\end{array}$ \\
\hline Inl & 1999 & $\begin{array}{c}-4.22 \\
(0)\end{array}$ & 1996 & $\begin{array}{c}-4.69 \\
(0)\end{array}$ & 1994 & $\begin{array}{c}-5.05 \\
(0)\end{array}$ \\
\hline $\begin{array}{l}\text { Critical } \\
\text { Values } \\
\% 1 \\
\% 5\end{array}$ & & & & $\begin{array}{l}93 \\
42\end{array}$ & $\begin{array}{l}-5 \\
-5\end{array}$ & \\
\hline
\end{tabular}

Note: Model A allows for a change in intercept, Model B permits a change in trend and Model C permits a change in both intercept and slope. The values in brackets denote the number of included lags of difference automatically selected by AIC.

Having determined that the variables are stationary in first differences, we conduct the ARDL cointegration procedure to examine whether the variables in question have common trends. In the first step of the Bonds testing procedure, we tested for the presence of the long-run relationship. The F-statistics tests the joint null hypothesis that the coefficients of the lagged level variables are zero indicating no long-run relationship between variables. Table 3 reports the results of the calculated F-statistics when each variable is considered as a dependent variable in the regression. In "a" type of all five models in the Table, we add inflation as the third variable. The lags lengths are selected as " 1 " according to the results of Breusch-Godfrey test. 
Table 3

Bounds Test Results for Cointegration

\begin{tabular}{|c|c|c|c|c|c|c|}
\hline \multicolumn{7}{|c|}{ Critical Value Bonds of the F Statistics: unrestricted intercept and no trend } \\
\hline \multirow{2}{*}{ k } & \multicolumn{2}{|c|}{$90 \%$ level } & \multicolumn{2}{|c|}{$95 \%$ level } & \multicolumn{2}{|c|}{$99 \%$ level } \\
\hline & $\mathrm{I}(0)$ & $\mathrm{I}(1)$ & $\mathrm{I}(0)$ & $\mathrm{I}(1)$ & $\mathrm{I}(0)$ & $\mathrm{I}(1)$ \\
\hline 1 & 4.145 & 4.950 & 5.125 & 6.000 & 7.400 & 8.510 \\
\hline 2 & 3.270 & 4.260 & 4.000 & 5.057 & 5.697 & 6.987 \\
\hline \multicolumn{7}{|c|}{$\begin{array}{c}\text { Calculated F Statistics } \\
\text { F(dependent variable/ independent variable(s)) }\end{array}$} \\
\hline Model 1 & $F(\ln G / \ln Y)$ & $: 2.99$ & $F(\ln Y / \ln G)$ & $: 1.304$ & & \\
\hline Model 1-a & $\mathrm{F}(\operatorname{lnG} / \ln Y, \ln \mathrm{l})$ & $: 5.716^{*}$ & $\mathrm{~F}(\ln Y / \ln G, \ln \mid)$ & $: 1.306$ & $\mathrm{~F}(\operatorname{lnl} / \ln \mathrm{Y}$ & $: 3.033$ \\
\hline Model 2 & $\mathrm{~F}(\ln G Y / \ln Y P)$ & $: 3.209$ & $F(\ln Y P / \ln G Y)$ & $: 1.107$ & & \\
\hline Model 2-a & $\mathrm{F}(\operatorname{InGY} / \operatorname{InYP}, \operatorname{Inl}$ & $: 6.347^{* *}$ & $\mathrm{~F}(\operatorname{InYP} / \ln \mathrm{GY}, \ln \mid)$ & ) $: 1.268$ & $\mathrm{~F}(\operatorname{lnl} / \ln \mathrm{Y}$ & Y) : 2.690 \\
\hline Model 3 & $\mathrm{~F}(\ln \mathrm{G} / \ln Y \mathrm{P})$ & $: 3.962$ & $\mathrm{~F}(\ln Y \mathrm{P} / \ln \mathrm{G})$ & $: 3.225$ & & \\
\hline Model 3-a & $\mathrm{F}(\ln \mathrm{G} / \ln Y \mathrm{P}, \ln \mathrm{l})$ & $: 6.706^{* *}$ & $\mathrm{~F}(\operatorname{lnYP} / \operatorname{|nG}, \ln \mid)$ & : 1.926 & $\mathrm{~F}(\ln \mid / \ln \mathrm{Y}$ & $: 3.163$ \\
\hline Model 4 & $\mathrm{~F}(\operatorname{lnGP} / \ln Y \mathrm{P})$ & $: 3.365$ & $\mathrm{~F}(\operatorname{lnYP} / \ln G P)$ & $: 1.617$ & & \\
\hline Model 4-a & $\mathrm{F}(\operatorname{InGP} / \ln Y \mathrm{P}, \operatorname{Inl}$ & $: 6.574^{* *}$ & $\mathrm{~F}(\ln Y \mathrm{P} / \ln \mathrm{gP}, \ln \mid)$ & $: 1.036$ & $\mathrm{~F}(\operatorname{lnl} / \ln \mathrm{Y}$ & P) $: 2.773$ \\
\hline Model 5 & $\mathrm{~F}(\ln G \mathrm{Y} / \ln Y)$ & $: 2.895$ & $F(\ln Y / \ln G Y)$ & $: 0.379$ & & \\
\hline Model 5-a & $\mathrm{F}(\ln \mathrm{G} Y / \ln Y, \ln \mathrm{l})$ & $: 5.714^{*}$ & $\mathrm{~F}(\ln Y / \ln G Y, \ln l)$ & $: 2.447$ & $\mathrm{~F}(\operatorname{lnl} / \ln \mathrm{Y}$ & : 3.032 \\
\hline
\end{tabular}

The lag lengths are selected as " 1 " by using AIC.

Critical values are extracted from Narayan (2005).

While the calculated F-statistics are less than the lower bounds at the 1\%, 5\% and $10 \%$ levels for Model 1, Model 2, Model 3, Model 4 and Model 5, they are higher than the upper bound levels for Model 1-a, Model 2-a, Model 3-a, Model 4-a and Model 5-a at the $5 \%$ level. Thus, the null hypotheses of no cointegration are accepted for all five versions of Wagner's law. When inflation variable is added as the third variable however, the null hypotheses are rejected indicating long-run relationships among the variables.

Once a long-run cointegration relationship is found between the variables, the second step is to estimate the long-run model for the dependent variable by selecting the orders of ARDL (n, m) model using the AIC. The orders of ARDL specifications are ARDL $(2,0,0)$ for Model 1-a, ARDL $(2,1,0)$ for Model 2-a, ARDL $(2,0,0)$ for Model 3-a, ARDL $(2,0,0)$ for Model 4-a and finally ARDL $(2,1,0)$ for Model 5-a. The results obtained by normalizing on dependent variables in the models in the long-run are reported in Table 4. 
Table 4

Long-Run Elasticities

\begin{tabular}{|c|c|c|c|c|}
\hline & $\begin{array}{c}\text { Dependent } \\
\text { Var. }\end{array}$ & $\begin{array}{l}\text { Coeffi- } \\
\text { cients }\end{array}$ & t-Statistics & \\
\hline Model 1-a ARDL $(2,0,0)$ & \multirow{4}{*}{$\ln G$} & & & \multirow{4}{*}{$e c t_{t-1}=\ln G-1.43 \ln Y+0.17 \ln \mid+5.73$} \\
\hline Constant & & -5.73 & -2.176 & \\
\hline $\ln Y$ & & 1.43 & -2.865 & \\
\hline Inl & & -0.17 & -2.001 & \\
\hline Model 2-a ARDL $(2,1,0)$ & \multirow{4}{*}{$\ln G P$} & & & \multirow{4}{*}{$e^{2} t_{t-1}=\operatorname{lnGP}-0.88 \operatorname{lnYP}+0.15 \ln \mid+4.65$} \\
\hline Constant & & -4.65 & -1.903 & \\
\hline $\operatorname{lnYP}$ & & 0.88 & -2.482 & \\
\hline Inl & & -0.16 & -1.867 & \\
\hline Model 3-a ARDL $(2,0,0)$ & \multirow{4}{*}{$\ln G$} & & & \multirow{4}{*}{$e t_{t-1}=\ln G-2.97 \ln Y P+0.23 \ln \mid-9.41$} \\
\hline Constant & & 9.41 & -1.593 & \\
\hline $\operatorname{lnYP}$ & & 2.97 & -2.773 & \\
\hline Inl & & -0.23 & -2.119 & \\
\hline Model 4-a ARDL $(2,0,0)$ & \multirow{4}{*}{$\operatorname{lnGP}$} & & & \multirow{4}{*}{$e^{e c t} t_{t-1}=\ln G P-1.92 Y P+0.16 \ln \mid+1.302$} \\
\hline Constant & & -1.302 & -1.873 & \\
\hline $\ln Y \mathrm{P}$ & & 1.92 & -2.435 & \\
\hline Inl & & -0.16 & -2.012 & \\
\hline Model 5-a ARDL $(2,1,0)$ & \multirow{4}{*}{$\ln G Y$} & & & \multirow{4}{*}{$e t_{t-1}=\ln G Y-0.41 \ln Y+0.15 \ln \mid+5.52$} \\
\hline Constant & & -5.52 & -1.398 & \\
\hline $\ln Y$ & & 0.41 & -1.907 & \\
\hline Inl & & -0.15 & -1.018 & \\
\hline
\end{tabular}

The estimated coefficients of the long-run relationships in the Table above, show that Wagner's law runs in Turkey in case of adding inflation as a third variable in the models. While real income has positive impacts, inflation has negative impacts on non-interest government expenditures as expected in all of the trivariate models. lnYP in Model 3-a has the highest impact on $\operatorname{lnG}$ by having 2.97 coefficient which means a $\% 1$ growth in $\operatorname{lnYP}$ leads to a $2.97 \%$ increase in $\operatorname{lnG}$. The lowest impact comes out in Model 5-a in which the coefficient of $\operatorname{lnY}$ is 0.41 implying a $0.41 \%$ growth in $\operatorname{lnGY}$ as a result of a $1 \%$ increase in $\ln Y$. On the other hand, when we include the impacts of inflation on non-interest government expenditures, we can easily observe from Table 5 that the biggest impact occurs in Model 3-a with the coefficient of -0.23 (which means a $\% 1$ increase in inflation rate results in a $0.23 \%$ decrease in $\operatorname{lnG}$ ) and the lowest occurs in Model 5-a with the coefficient of -0.15 (which means a $1 \%$ increase in inflation rate causes a $0.15 \%$ decrease in $\ln G$ ). 
Table 5

Short-Run Elasticities

\begin{tabular}{|c|c|c|c|c|c|}
\hline Model & Variable & Coefficient & Std. Error & t-Statistics & t-Prob. \\
\hline \multirow{5}{*}{ Model 1-a: } & C & 0.015402 & 0.011803 & 1.304853 & 0.0486 \\
\hline & $\Delta \ln G(-1)$ & -0.236316 & 0.045260 & -5.221326 & 0.0000 \\
\hline & $\Delta \ln G(-2)$ & -0.052008 & 0.046411 & -1.120610 & 0.2684 \\
\hline & $\Delta \ln Y$ & 0.536232 & 0.083204 & 6.444752 & 0.0000 \\
\hline & $\Delta \ln Y(-1)$ & 0.523829 & 0.098305 & 5.328584 & 0.0000 \\
\hline \multirow[t]{2}{*}{$\ln G / \ln Y, \ln \mid$} & $\Delta I n Y(-2)$ & 0.362393 & 0.113015 & 3.206586 & 0.0025 \\
\hline & $\Delta l n l$ & -0.044538 & 0.009160 & -4.862021 & 0.0000 \\
\hline \multirow[t]{4}{*}{$\operatorname{ARDL}(2,2,3)$} & $\Delta \ln l(-1)$ & -0.033689 & 0.009094 & -3.704652 & 0.0006 \\
\hline & $\Delta \operatorname{lnl}(-2)$ & -0.024205 & 0.008522 & -2.840476 & 0.0067 \\
\hline & $\Delta \operatorname{lnl}(-3)$ & -0.019753 & 0.007897 & -2.501325 & 0.0161 \\
\hline & ecm(-1) & -1.057145 & 0.050534 & 20.91956 & 0.0000 \\
\hline \multirow[b]{5}{*}{ Model 2-a: } & $\mathrm{C}$ & 0.017383 & 0.008108 & 2.143964 & 0.0376 \\
\hline & $\Delta \operatorname{lnGY}(-1)$ & -0.210017 & 0.052098 & -4.031235 & 0.0002 \\
\hline & $\Delta \ln G Y(-2)$ & -0.051245 & 0.054669 & -0.937364 & 0.3537 \\
\hline & $\Delta \ln G Y(-3)$ & -0.065728 & 0.054318 & -1.210055 & 0.2327 \\
\hline & $\Delta I n Y P$ & 0.077662 & 0.086025 & -6.703008 & 0.0000 \\
\hline \multirow{2}{*}{ InGY / InYP, Inl } & $\Delta \ln Y P(-1)$ & 0.463768 & 0.108110 & 4.289794 & 0.0001 \\
\hline & $\Delta \ln Y P(-2)$ & 0.309566 & 0.118602 & 2.610114 & 0.0123 \\
\hline \multirow{5}{*}{$\operatorname{ARDL}(3,2,3)$} & $\Delta l n l$ & -0.048033 & 0.010581 & -4.539389 & 0.0000 \\
\hline & $\Delta \operatorname{lnl}(-1)$ & -0.032985 & 0.010378 & -3.178311 & 0.0027 \\
\hline & $\Delta I n I(-2)$ & -0.019922 & 0.009719 & -2.049896 & 0.0464 \\
\hline & $\Delta \ln l(-3)$ & -0.018860 & 0.009242 & -2.040627 & 0.0473 \\
\hline & ecm $(-1)$ & -1.057362 & 0.058345 & 18.12265 & 0.0000 \\
\hline \multirow[b]{5}{*}{ Model 3-a: } & $\mathrm{C}$ & 0.032893 & 0.006404 & 5.136285 & 0.0000 \\
\hline & $\Delta \ln G(-1)$ & -0.228260 & 0.034211 & -6.672121 & 0.0000 \\
\hline & $\Delta \ln G(-2)$ & 0.017768 & 0.034839 & 0.509994 & 0.6126 \\
\hline & $\Delta I n Y P$ & 0.580439 & 0.058613 & 9.902951 & 0.0000 \\
\hline & $\Delta \ln Y P(-1)$ & 0.481915 & 0.063474 & 7.592333 & 0.0000 \\
\hline \multirow{2}{*}{$\ln G / \ln Y P, \ln l$} & $\Delta I n Y P(-2)$ & 0.307146 & 0.072510 & 4.235939 & 0.0001 \\
\hline & $\Delta \ln Y P(-3)$ & 0.350271 & 0.081612 & 4.291903 & 0.0001 \\
\hline \multirow{5}{*}{$\operatorname{ARDL}(2,3,3)$} & $\Delta l n l$ & -0.038630 & 0.006954 & -5.555344 & 0.0000 \\
\hline & $\Delta \ln l(-1)$ & -0.026741 & 0.006923 & -3.862959 & 0.0004 \\
\hline & $\Delta \operatorname{lnl}(-2)$ & -0.016605 & 0.006311 & -2.631110 & 0.0117 \\
\hline & $\Delta \ln l(-3)$ & -0.011137 & 0.006033 & -1.845816 & 0.0717 \\
\hline & ecm(-1) & -1.074297 & 0.037590 & 28.57939 & 0.0000 \\
\hline \multirow[b]{4}{*}{ Model 4-a: } & $\mathrm{C}$ & 0.020743 & 0.006358 & 3.262655 & 0.0021 \\
\hline & $\Delta \ln G P(-1)$ & -0.262604 & 0.040161 & -6.538810 & 0.0000 \\
\hline & $\Delta I n Y P$ & 0.536848 & 0.070897 & 7.572169 & 0.0000 \\
\hline & $\Delta \ln Y P(-1)$ & 0.458525 & 0.078382 & 5.849858 & 0.0000 \\
\hline \multirow{2}{*}{ InGP / InYP, Inl } & $\Delta I n Y P(-2)$ & 0.295156 & 0.089896 & 3.283290 & 0.0020 \\
\hline & $\Delta l n l$ & -0.039831 & 0.008154 & -4.884835 & 0.0000 \\
\hline \multirow{4}{*}{$\operatorname{ARDL}(1,2,3)$} & $\Delta \ln l(-1)$ & -0.029840 & 0.008134 & -3.668414 & 0.0006 \\
\hline & $\Delta \ln l(-2)$ & -0.020204 & 0.007712 & -2.619619 & 0.0119 \\
\hline & $\Delta \ln l(-3)$ & -0.016951 & 0.007462 & -2.271472 & 0.0278 \\
\hline & ecm(-1) & -1.076218 & 0.047101 & 22.84922 & 0.0000 \\
\hline
\end{tabular}




\begin{tabular}{|c|c|c|c|c|c|}
\hline \multirow{5}{*}{ Model 5-a } & C & 0.008981 & 0.013120 & 0.684527 & 0.4971 \\
\hline & $\Delta \ln G Y(-1)$ & -0.200314 & 0.050259 & -3.985609 & 0.0002 \\
\hline & $\Delta \ln Y$ & 0.066350 & 0.094644 & -6.709997 & 0.0000 \\
\hline & $\Delta \ln Y(-1)$ & 0.487093 & 0.120703 & 4.035449 & 0.0002 \\
\hline & $\Delta \ln Y(-2)$ & 0.408261 & 0.129560 & 3.151145 & 0.0029 \\
\hline \multirow{5}{*}{$\begin{array}{l}\text { InGY / InY, Inls } \\
\text { ARDL(1,2,3) }\end{array}$} & $\Delta|n|$ & -0.051625 & 0.010142 & -5.090223 & 0.0000 \\
\hline & $\Delta \mid n l(-1)$ & -0.039499 & 0.010139 & -3.895737 & 0.0003 \\
\hline & $\Delta \ln \mid(-2)$ & -0.023701 & 0.009656 & -2.454590 & 0.0179 \\
\hline & $\Delta \operatorname{lnl}(-3)$ & -0.020812 & 0.009058 & -2.297716 & 0.0262 \\
\hline & ecm(-1) & -1.047669 & 0.058335 & 17.95958 & 0.0000 \\
\hline
\end{tabular}

In the final step of the ARDL cointegration procedure short-run dynamic parameters obtained from equation 3 are given in Table 5. In all of the models in the Table, coefficients of the error correction terms are found negative (and bigger than " 1 " in absolute term) and statistically significant. Thus, the signs of the short-run dynamic impacts are maintained in the long-run. In all "a" type model versions aiming to test the validity of the Wagner's law, it's observed that real income has positive impacts on non-interest government expenditures in every period. Besides inflation ratio negatively affects non-interest government expenditures.

\section{Conclusion}

In this study, we examined Wagner's law for Turkey by performing a recent cointegration technique on non-interest government expenditures over the period 1950-2010 using time series data. In order to test validity of the Law, six widely cited specifications have been estimated.

This study differs from the other studies aiming to test the Wagner's law in Turkey in some ways. First this study attempts to analyse the relationship between income and "non-interest government expenditures" instead of total government expenditures in order to search for evidence supporting Wagner's law. Second, this study investigates the validity of Wagner's law in Turkey in a trivariate system adding inflation as the third variable. There exist too few studies examining the relationship between government expenditures and income in a trivariate system and to the best of our knowledge, no empirical study on Turkey includes inflation as the third variable in the cointegration equation.

In order to find out the significance of omitted variables, we apply the autoregressive distributed lag (ARDL) cointegration technique on a bivariate system first and on a trivariate system next. The test results of the five bivariate models examined regarding to Wagner's hypothesis indicates no long-run relationship between non-interest government expenditures and national income. On our next attempt within the trivariate system framework, we include the inflation rate to our previous bivariate systems. The inclusions of the third variable to the models reestablish the long-run relationship 
between non-interest government expenditures and national income. In other words, while there does not exist any relationship between non-interest real government expenditure and real GNP, the relationship occurs in case of introducing the inflation ratio. In other words, while we could not find any evidence supporting the Wagner's law in the bivariate system, in case we introduce inflation ratio as the third variable we found that an increase in national income does affect non-interest government expenditures meaning that the relationship in question occurs. Therefore, as we expect, inflation plays an important role in the formation of the causal process between government expenditures and national income.

\section{References}

Abizadeh, S., Yousefi, M. (1998), "An Empirical Aanalysis of South Korea's Economic Development and Public Expenditures Growth." Journal of Socio-economics, Vol. 27, No. 6, pp. 687-701.

Ahsan, S. M., Kwan, A. C., Sahni, B. S. (1992), "Public Expenditure and National Income Causality: Further Evidence on the Role of Omitted Variables." Southern Economic Journal, Vol. 58, No.3, pp. 623-634.

Ahsan, S. M., Kwan, A. C., Sahni, B. S. (1996), "Cointegration and Wagner's Hypothesis: Time Series Evidence for Canada." Applied Economics, Vol. 28, No. 8, pp. 1055-1058.

Akyuz, Y., Boratav, K. (2002), "The Making of the Turkish Financial Crisis." UNCTAD Discussion Papers, No: 158. April, 2002. Available from http://www.unctad.org/en/docs/dp_158.en.pdf

Arisoy, I. (2005), “Wagner ve Keynes Hipotezleri Cercevesinde Turkiye'de Kamu Harcamalari ve Ekonomik Buyume lliskisi." C.U. Sosyal Bilimler Dergisi, Vol. 14, No. 2, pp. 63-80.

Ashworth, J. (1994), "Spurious in Mexico: A Comment on Wagner's Law." Public Finance/Finances Publiques, Vol. 49, No. 2, pp. 282-286.

Bagdigen, M., Cetintas, H. (2004), "Causality between Public Expenditure and Economic Growth: The Turkish Case." Journal of Economics and Social Research, Vol. 6, No. 1, pp. 53-72.

Bagdigen, M., Beser, B. (2009), "Ekonomik Buyume ile Kamu Harcamalari Arasindaki Nedensellik Iliskisinin Wagner Tezi Kapsaminda Bir Analizi: Turkiye Ornegi.” ZKU Sosyal Bilimler Dergisi, Vol. 5, No. 9, pp. 1-17.

Basar, S., Aksu, H., Temurlenk, S., Polat, O. (2009), "Turkiye'de Kamu Harcamalari ve Buyume Iliskisi: Sinir Testi Yaklasimi.” Ataturk Universitesi Sosyal Bilimler Enstitusu Dergisi, Vol. 13, No. 1, pp. 301-314.

Bird, R. M. (1971), "Wagner's Law: a Pooled Time Series and Cross Section Comparison." National Tax Journal, Vol. 38, pp. 209-218.

Cavusoglu, A. T. (2005), “Testing the Validity of Wagner's Law in Turkey: The Bounds Testing Approach.” Ankara Universitesi Siyasal Bilgiler Fakultesi Dergisi, Vol. 60, No. 1, pp. 73-87.

Celasun, M. (1990), "Fiscal Aspects of Adjusment in the 1980s." In Tosun A., Dani, R. (eds.), The Political Economy of Turkey. London: The McMillan Press, pp.37-59.

Chletos, M., Kollias, C. (1997), "Testing Wagner's Law Using Disaggregated Public Expenditure Data in the Case of Greece: 1958-1993." Applied Economics, Vol. 29, pp. 371-377.

Courakis, A. S., Moura-Roque, F., Tridimas, G. (1993), "Public Expenditure Growth in Greece and Portugal: Wagner's Law and beyond." Applied Economics, Vol. 25, No. 1, pp. 125-134.

Demirbas, S. (1999), "Co-integration Analysis-causality Testing and Wagner's Law: The Case of Turkey, 1950-1990." University of Leicester Discussion Papers, 99/2, available at: www.le.ac.uk/ economics/research/RePEc/lec/leecon/econ99-3.pdf.

Dickey, D. A., Fuller, W. A. (1979), "Distribution of the Estimators for Autoregressive Time Series with a Unit Root." Journal of the American Statistical Association, Vol. 74, pp. 427-431. 
Dritsakis, N., Adamopoulos, A. (2004), "A Causal Relationship between government Spending and Economic Development: an Empirical Examination of the Greek Economy." Applied Economics, Vol. 36, No. 5, pp. 457-464.

Dutt, S. D., Ghosh, D. (1997), "An Empirical Examination of the Public Expenditure- Economic Growth Correlations." Southwest Oklahoma Economic Review, Vol. 12, No. 4, pp. 14-26.

Elliott, G., Rothenberg, T. J., Stock, J. H. (1996), "Efficient Tests for an Autoregressive Unit Root." Econometrica, Vol. 64, No. 4, pp. 813-836.

Engle, R. F., Granger, C. W. (1987), "Co-integration and Error Correction: Representation, Estimation and Eesting." Econometrica, Vol. 55, No. 2, pp. 251-276.

Ertugrul, A., Selcuk, F. (2001), "A Brief Account of the Turkish Economy, 1980-2000." Russian and East European Finance and Trade, Vol. 37, No. 6, pp. 6-30.

Ghali, H. K. (1998), "Government Size and Economic Growth: Evidence from a Multivariate Cointegration Analysis." Applied Economics, Vol. 31, pp. 975-987

Ghate, C., Zak, P. J. (2002), "Growth of Government and the Politics of Fiscal Policy." Structural Change and Economic Dynamics, Vol. 13, No. 4, pp. 435-455.

Goffman, J. J., (1968), "On the Empirical Testing of Wagner's Law: a Technical Note." Public Finance/ Finances Publiques, Vol. 3, No. 3, pp. 359-364.

Gunaydin, I. (2000): "Turkiye Icin Wagner ve Keynes Hipotezlerinin Testi." Iktisat, Isletme ve Finans, No. 175 , pp. $70-86$.

Gupta, S. P., (1967), "Public Expenditure and Economic Growth: a Time Series Analysis." Public Finance/Finances Publiques, Vol. 22, No. 4, pp. 423-461.

Gyles, A. F. (1991), "A Time Domain Transfer Function Model of Wagner's Law: the Case of the United Kingdom Economy." Applied Economics, Vol. 23, No. 2, pp. 327-330.

Halicioglu, F. (2003), "Testing Wagner's Law for Turkey, 1960-2000." Review of Middle East Economics and Finance, Vol. 1, No. 2, pp. 129-140.

Hayo, B. (1994), "No Further Evidence of Wagner's Law for Mexico." Public Finance/Finances Publiques, Vol. 49, No. 2, pp. 287-294.

Henrekson, M. (1993), “Wagner's Law: a Spurious Relationship?” Public Finance/Finances Publiques, Vol. 48, No. 2, pp. 406-415.

Hondroyiannis, G., Papapetrou, E. (1995), “An Examination of Wagner's Law for Greece: a Cointegration Analysis." Public Finance/Finances Publiques, Vol. 50, No. 1, pp. 67-79.

Isik, N., Alagoz, M. (2005), "Kamu Harcamalari ve Buyume Arasindaki lliski." Erciyes Universitesi IIBF Dergisi, No. 24, pp. 63-75.

Johansen, S. (1988), "Statistical and Hypothesis Testing of Co-integration Vectors." Journal of Economic Dynamics and Control, Vol. 12, pp. 231-254.

Johansen, S., Juselius, K. (1990), "Maximum Likelihood Estimation and Inference on Co-integration with Applications to the Demand for Money." Oxford Bulletin of Economics, Vol. 52, pp. 169-210.

Krzyzaniak, M. (1974), "The Case of Turkey: Government Expenditures, The Revenue Constraint and Wagner's Law." Growth and Change, Vol. 5, No. 2, pp. 13-19.

Kumar, S., Webber, D. J., Fargher, S. (2009), "Wagner's Law Revisited: Cointegration and Causality Tests for New Zealand." University of the West of England Discussion Papers, No: 917.

Legrenzi, G., Milas, C. (2002), "A Multivariate Approach to the Growth of Governments." Public Finance Review, Vol. 30, No. 1, pp. 56-76.

Lin, C. (1998), "'Structural' Wagner's Law and Institutional Dynamics: an Evolutionary Perspective." Public Finance/Finances Publiques, Vol. 53, No. 2, pp. 175-194.

Loizides, J., Vamvoukas, G. (2005), "Government Expenditure and Economic Growth: Evidence from Trivariate Causality Testing." Journal of Applied Economics, Vol. 8, No.1, pp. 125-152.

Mann, A. J. (1980), "Wagner's Law: an Econometric Test for Mexico, 1925-1976." National Tax Journal, Vol. 33, No, 2, pp. 189-201.

Musgrave, R. A. (1969), Fiscal Systems. New Haven and London: Yale University Press. 
Michas, N. A. (1975), "Wagner's Law of Public Expenditures: What Is Appropriate Measurement for a Valid Test." Public Finance/Finances Publiques, Vol. 30, No. 1, pp. 77-84.

Mohammadi, H., Cak, M., Cak, D. (2008), "Wagner's Hypothesis: New Evidence from Turkey Using the Bounds Testing Approach." Journal of Economics Studies, Vol. 35, No. 1, pp. 94-106.

Murthy, N. R. V. (1993), "Further Evidence of Wagner's Law for Mexico: an Application of Cointegration Analysis." Public Finance/Finances Publiques, Vol. 48, No. 1, pp. 92-96.

Narayan, P. K. (2005), "The Saving and Investment Nexus for China: Evidence from Cointegration Tests." Applied Economics, Vol. 37, pp. 1979-1990.

Oktayer, A. (2011), Turkiye'de Ekonomik Buyume ve Kamu Harcamalari Arasindaki Iliskinin Analizi: 1950-2009." Istanbul Universitesi Iktisat Fakultesi Mecmuasi, Vol. 61, No. 1 (forthcoming).

Oktayer, N., Susam, N. (2008), "Kamu Harcamalari-Ekonomik Buyume Iliskisi: 1970-2005 Yillari Turkiye Ornegi." Ataturk Universitesi Iktisadi ve Idari Bilimler Dergisi, Vol. 22, No. 1, pp. 145-164.

Oxley, L. (1994), "Cointegration, Causality and Wagner's Law: a Test for Britain 1870-1913." Scottish Journal of Political Economy, Vol. 41, No. 3, pp. 286-298.

Ozatay, F. (1999) "Populist Policies and the Role of Economic Institutions in the Performance of the Turkish Economy." Yapi Kredi Economic Review, Vol. 10, No. 1, pp. 13-26.

Payne, J. E., Ewing, B. T., Mohammadi, H. (2006), "Wagner's Hypothesis: New Evidence from the US Using the Bounds Testing Approach." In Ott, A. F., Cebula, R. T. (eds), The Elgar Companion to Public Economics, Empirical Public Economics. Edward Elgar, Aldershot, pp. 30-40.

Peacock, A. T., Wiseman, J. (1961), The Growth of Public Expenditure in the United Kingdom. Princeton: Princeton University Press.

Peacock, A. T., Wiseman, J. (1979), "Approaches to the Analysis of Government Expenditure Growth." Public Finance Quarterly, Vol. 7, No. 1, pp. 3-23.

Perron, P. (1989), "The Great Crash, the Oil Price Shock, and the Unit Root Hypothesis." Econometrica, Vol. 57, No. 6, pp.1361-1401.

Pesaran, M. H., Shin, Y., Smith, R. J. (2001), "Bounds Testing Approaches to the Analysis of Level Relationships." Journal of Applied Econometrics, Vol. 16, No. 3, pp. 289-326.

Pryor, F. L. (1968), Public Expenditure in Communist and Capitalist Nations. London: George Allen and Unwin.

Ram, R. (1986), "Causality between Income and Government Expenditure: a Broad International Perspective." Public Finance/Finances Publiques, Vol. 31, No. 3, pp. 393-413.

Ram, R. (1987), "Wagner's Hypothesis in Time-series and Cross-section Perspectives: Evidence from Real Data from 115 Countries." Review of Economics and Statistics, Vol. 69, No. 2, pp. 194-204.

Sari, R. (2003), "Kamu Harcamalarinin Dunyada ve Turkiye'de Gelisimi ve Turkiye'de Ulusal Gelir ile Iliskisi." Iktisat, Isletme ve Finans, Vol. 18, pp. 25-38.

Singh, B., Sahni, B. S. (1984), "Causality between Public Expenditure and National Income." Review of Economics and Statistics, Vol. 66, No. 4, pp. 630-644.

Sinha, D., (2007), "Does the Wagner's Law Holds for Thailand? A Time Series Study." MPRA Paper, No: 2560.

Terzi, H. (1998), "Kamu Harcamalari ile Ekonomik Kalkinma lliskisi Uzerine Ekonometrik Bir Inceleme." Iktisat, Isletme ve Finans, Vol. 13, pp. 67-78.

Yamak, N., Kucukkale, Y. (1997), “Turkiye'de Kamu Harcamalari-Ekonomik Buyume lliskisi.” Iktisat, Isletme ve Finans, Vol. 131, pp. 5-14.

Yay, G., Yay, T., Tastan, H. (2002), „The Impact of Budget Deficits on Output and Inflation in Turkey During the Period 1967-1999." Yapi Kredi Economic Review, Vol. 13, No. 2, pp. 55-67.

Yay, T., Tastan, H. (2009), "Growth of Public Expenditures in Turkey During the 1950-2004 Period: An Econometric Analysis." Romanian Journal of Economic Forecasting Vol. 4, pp. 101-118.

Zivot, E., Andrews, D. W. K. (1992), "Further Evidence on the Great Crash, the Oil-Price Shock, and the Unit-Root Hypothesis." Journal of Business Economic Statistics, Vol. 10, pp. 251-270. 